\title{
Entrepreneurial Skills Required By Secondary School Graduates for Success in the Tourism Industry in Cross River State, Nigeria
}

\author{
D. A. Alawa\& A. E. Dijeh \\ Department of Vocational and Special Education, University of Calabar, Cross River State, Nigeria
}

\begin{abstract}
This study was designed to identify the entrepreneurial skills required by secondary school graduates for success in the tourism industry in Cross River State, Nigeria. Three research questions and hypotheses guided the study. The study made use of survey research design. The population for the study was 1,332 comprising 112 graduate tourism personnel in the Cross River State Tourism Commission and 1,220 Vocational subject teachers in public secondary schools in the State. The Sample for the study was 356 respondents. A 20 percent proportionate sample was used to select the sample of vocational subject teacher (244 respondents) through simple random sampling technique while the entire population of tourism personnel (112) was involved in the study. A 32 item questionnaire tagged Entrepreneurial Skills Requirements in Tourism Industry Questionnaire (ESRTIQ) was the instrument for data collection and was validated by three experts. Split half and Pearson Product Moment Correlation was used to determine the stability of the instrument and a coefficient of 0.82 was obtained. Weighted mean scores were used to answer the research questions while Independent $t$ test statistic was used to test the null hypotheses at .05 level of significance. From the data collected and analyzed, it was found out that secondary school graduates required entrepreneurial skills training in planning for establishment of business outlets; implementing the business plan and marketing products in any chosen business outlet in the tourism industry. It was recommended that the identified entrepreneurial skills areas be integrated into the skill training programme of the state so that youths and adults can be trained to take advantage of the business opportunities in the tourism industry.
\end{abstract}

Key Words: Entrepreneurial Skills, Secondary School Graduates, Tourism Industry

\section{Introduction}

Tourism is one of the fastest growing industries in the world. The World Tourism Organization (1998) described tourism as an activity which involves the travelling of persons to places outside their usual environment for leisure. In the opinion of Okoli (2001), tourism is the development and provision of infrastructure and superstructure. The author explained that these infrastructures, such as, roads, water supply, community systems among others and superstructures like hotels, motels, guest houses must be adequately maintained for tourism to develop. Tourism in the context of this study is the development and provision of infrastructure, superstructure and business opportunities that provide ideal conditions for persons to visit outside of their homes for leisure or economic gains. Tourism is undertaken for some benefits. Oh (2005) stated that tourism benefits the individual tourist, tourist organization and local communities in terms of employment, income and enhancement to the quality of life. Ayeni and Ebohom (2013) noted that the tourism industry is a major avenue for commodity exports and a significant source of foreign exchange that allows internal and external trade balances to be reconciled thus, making the industry to be business oriented. Tourism accounts for $8.1 \%$ of the Gross Domestic Products (GDP) of Nigeria as a result of the numerous tourism potentials in the country (Eja, 2010). These potentials according to Larry (2005) ranged from natural to manmade, such as, the table mountain, colourful folks, beautiful landscape, overwhelming serenity and agreeable climate that welcomes fun seekers to the highlands of Nigeria. The benefits from the tourism industry which are in the areas of economic development, employment generation and overall enhancement of living conditions make it imperative for tourism resources to be managedmore so that the tourism industry is fast becoming an enterprise.

An enterprise in the opinion of Osuala (2004) is any business organization engaged in an economic activity irrespective of its legal forms. In the view of Abbott in Ogungbade, Alkali and Ibekwe (2010), an enterprise is a business operation undertaken by a body which may be one person, a family, a company or cooperative for a particular production or marketing activities.In the context of this study, an enterprise is a business operation which could be undertaken by secondary school graduates, that is, students who have completed this senior secondary education but are not admitted into higher institution or sufficiently engaged in the various activities in the tourism industry as workers or owners of business outfits to earn a living. These activities as it concerns the youths and tourism industry include planning, implementation and marketing of products for profit maximization of the enterprise.The resources of an enterprise must be prudently utilized by entrepreneurs for business goals to be achieved. 
An entrepreneur in the opinion of Onu (2007) is an investor, innovator and developer of an enterprise. The author explained that the entrepreneur sees to the overall affairs of the enterprise through his ability to manage human and material resources. Ochonorgor and Ohwovoriole (2007) said that an entrepreneur should have the ability of combining human and material resources effectively to provide goods and services to the society. An entrepreneur in the tourism industry is an individual who is knowledgeable in setting goals, implementing the goals by combining resources to provide goods and services as well as marketing of the products from a particular enterprise within the industry. An entrepreneur therefore needs to be skilled in order to perform these activities efficiently.

Skill according to Osinem (2008) is the expertness, practiced ability or proficiency displayed in the performance of a task. The author explained that it is the ability to perform a task acquired through repetition of the operation. In the opinion of Okorie (2000), to possess a skill is the demonstration of acting, thinking or behaving in a specific activity in such a way that the process becomes natural to the individual through repetition or practice. Skill in the context of this study is the ability of secondary school graduates to perform the various activities in the tourism industry as well as being self reliant by operating any business firm within the industry as entrepreneurs. The possession of these skills by youths with maximum proficiency constitutes entrepreneurial skills.

The tourism industry in Cross River State comprise hotels, tourist site like Qua falls, Agbokim waterfalls, Cross River National Park, Obudu Cattle Ranch, Christmas Carnival Festival, Leboku New yam festival and so on that provide employment and business opportunities for secondary school graduates. Regrettably, the researchers have observed that the tourism industry is not fully explained to students in secondary schools as a money generating entity in subjects like Geography, Home Economics, Agricultural Science and Social Studies. All that is done by teachers is the mere mention of the tourism sites and benefits with no regards to skill development which builds entrepreneurship zeal in students andprepare them to explore business opportunities in the tourism industry. This propels these youths to chase after white collar jobs to cities and end up as arm robbers and prostitutes when they are not successful. Interactions with some officials from the State Tourism Commission and hotel owners reveal that most youth lack basic employable skills in the utilization of resources and execution of activities as well as entrepreneurial skills to take advantage of business opportunities in the industry. Conversely, if skills in the various activities in the tourism enterprise are identified, packaged into training programmes and integrated into skills acquisition centres for training unemployed youths, it could help to provide occupational opportunities for interested youths as well as school leavers thereby making them to positively contribute to building the economy of the nation and reduce attendant vices posed by idleness.

The researcher's concern over the above observations necessitated this study to identify the entrepreneurial skills required by secondary school graduates for success in the tourism industry in Cross River State. Specifically, the study seeks to identifyentrepreneurial skills required by secondary school graduates in;

a. planning for the establishment of small scale business out lets in the tourism industry.

b. implementing business plans in the tourism industry.

c. marketing of products in business outlets within the tourism industry.

\section{Methodology}

Three research questions and hypotheses guided the study. Survey research design was adopted for the study. Survey research design according to Nworgu (2006) is a design in which group of people or items is studied by collecting and analyzing data from a few people or items considered to be representative of the entire group. The study was carried out in Cross River State, Nigeria. The population for the study was 1,332 comprising 112 graduate tourism personnel from the Cross River State Tourism Commission and 1,220 vocational subject teachers, that is, Business Education (528); Agricultural Science (730) and Home Economics (38) from public schools in the State Secondary School Education Board.The sample for the study was 356 respondents made up of 112 tourism personnel and 244 vocational subject teachers. A simple random sampling technique (balloting) was used to select 20 percent of the Vocational subject teachers in the three areas isolated for the study. This choice of $20 \%$ agrees with the submission of Uzoagulu (1998) that when a defined population is in a few thousands $20 \%$ or more could be used to reduce sampling error. The entire population of graduate tourism personnel was involved in the study because of its small and manageable size.A 32 item questionnaire tagged Entrepreneurial Skills Requirements in Tourism Industry Questionnaire (ESRTIQ) was the instrument for data collection. The instrument had two sections; A and B. Section A solicited demographic data of the respondents while section B dealt with research variables in the study with the following scale: Very Highly Required - VHR; Highly Required - HR; Moderately Required -MR and Not Required -NR. The highest level in the scale had 4 points and the least received 1point. The instrument was face validated by three experts. One of the experts each was from Agricultural Education unit, Home Economic Education unit and Business Education unit of the Department of Vocational and Special Education, University of Calabar. Split half 
technique and Pearson Product Moment Correlation Coefficient were used to determine the stability of the instrument and a coefficient of 0.82 was obtained. One thousand two hundred and ninety six copies of the questionnaire were administered on the respondents with the help of ten (10) hired and trained research assistants on a face to face basis and retrieved with a 100 per cent return rate. The data collected was analyzed using weighted mean scores to answer the research questions and Independent $t$-test statistic to test the null hypotheses at .05 level of significance and 1295degreeof freedom.

The following decisions guided the interpretation of the results of analysis made:

a) A cut off point of 2.50 was used for answering the research questions.

b) For the hypotheses, the null hypotheses was upheld if the calculated t-value was less than critical table value of 1.960 otherwise; the alternate hypotheses was upheld at .05 level of significance.

\section{Results} this study

The results of the study were obtained from the research questions answered and hypotheses tested in

\section{Result Question 1}

What entrepreneurial skills are required by secondary school graduates in planning for the establishment of small scale business outlets in the tourism industry?

\section{Hypothesis One}

There is no significant difference in the mean ratings of tourism personnel and vocational subject teachers on entrepreneurial skills required by secondary school graduates in planning for the establishment of small scale business out lets in the tourism industry.

The data for answering research question one and hypothesis one are presented in table one.

\begin{tabular}{|c|c|c|c|c|c|c|c|}
\hline SN & Item Statement & $\overline{\mathrm{X}}$ & SD & t-cal & t-tab & $\mathbf{R Q}$ & Ho \\
\hline 1 & $\begin{array}{l}\text { Establish goals and standards for the business } \\
\text { in the Tourism Industry }\end{array}$ & 3.38 & 0.732 & 1.162 & 1.960 & Required & $\begin{array}{l}\text { Not } \\
\text { Significant }\end{array}$ \\
\hline 2 & Decide on the nature of business & 3.24 & 0.811 & 1.013 & 1.960 & & “ \\
\hline 3 & $\begin{array}{l}\text { Develop rules and procedures for the } \\
\text { enterprise }\end{array}$ & 3.00 & 0.854 & 0.466 & 1.960 & “ & “ \\
\hline 4 & $\begin{array}{l}\text { Identify personnel that would assist in the } \\
\text { enterprise }\end{array}$ & 2.78 & 1.213 & 0.563 & 1.960 & “ & “ \\
\hline 5 & $\begin{array}{l}\text { Fix wages and incentives for the business } \\
\text { assistants (if any) }\end{array}$ & 3.21 & 0.733 & 1.221 & 1.960 & " & " \\
\hline 6 & $\begin{array}{l}\text { Identify source of funds for the enterprise } \\
\text { Identify purchase outlets for procurement of }\end{array}$ & 3.14 & 0.801 & 1.320 & 1.960 & “ & " \\
\hline 7 & $\begin{array}{l}\text { inputs } \\
\text { Prepare a budget for the enterprise in the }\end{array}$ & 3.32 & 0.773 & 0.464 & 1.960 & “ & “ \\
\hline 8 & $\begin{array}{l}\text { industry } \\
\text { Identify other resources necessary for the take }\end{array}$ & 3.54 & 0.910 & 0.421 & 1.960 & “ & “ \\
\hline 9 & off of the enterprise & 3.18 & 0.721 & 0.731 & 1.960 & “ & “ \\
\hline
\end{tabular}

Key: $\bar{X}=$ Mean; $S D=$ Standard Deviation; $R Q=$ Research Question; Ho=Null Hypothesis

Table 1 presents the mean ratings of respondents on entrepreneurial skills required by secondary school graduates in planning for the establishment of small scale business outlets in the tourism industry. The table shows that the nine isolated items recorded mean ratings between 2.78 and 3.54 which are above 2.50 cut-off point on a four point scale. The result shows that the nine entrepreneurial skills items are required by secondary school graduates in planning for the establishment of small scale business out lets in the tourism industry. This implies that secondary school graduates require skills in establishing goals and business standards, deciding on the nature of the business, developing rules and procedures for the enterprise, identifying supportive personnel and sources of funds among others to be able to plan for the establishment of any business outlet in the tourism industry and take advantage of the benefits therein. The standard deviation ranged from 0.721 to 1.213 which revealed that respondents were not too far from the mean and each other in their responses.

The hypothesis tested in table 1 revealed that the nine entrepreneurial skill items had their calculated tvalues ranged from 0.421 to 1.320 which were less than table value of 1.960 at .05 level of significance and 354 degree of freedom. This indicated that there is no significant difference in the mean ratings of the two groups of respondents on the nine skill items required by secondary school graduates for planning for the establishment of 
small scale business outlets in the tourism industry. The null hypothesis was upheld for the for the nine entrepreneurial skill items.

\section{Research Question 2}

What entrepreneurial skills are required by secondary school graduates in implementing business plans in the tourism industry?

\section{Hypothesis Two}

There is no significant difference in the mean ratings of tourism personnel and vocational subject teachers on entrepreneurial skills required by secondary school graduates in implementing business plans in the tourism industry.

The data for answering research question two and hypothesis two are presented in table two.

Table 2Mean Ratings and t-test Analysis of the Responses of Vocational Subject teachers and Tourism personnel on Entrepreneurial Skills Required by Secondary School Graduates in Implementing Business plans in the Tourism Industry

\begin{tabular}{|c|c|c|c|c|c|c|c|}
\hline SN & Item Statement & $\bar{X}$ & SD & t-cal & t-tab & RQ & Ho \\
\hline 1 & $\begin{array}{l}\text { Procure the various materials, equipment and goods necessary } \\
\text { for the take off of the business according to plan }\end{array}$ & & & & & & \\
\hline 2 & $\begin{array}{l}\text { Organize or arrange the materials or goods to attract the } \\
\text { attention of customers }\end{array}$ & 3.01 & 0.771 & 0.536 & 1.960 & Rqrd & NS \\
\hline & Share jobs to subordinates within the business plan & 2.97 & 0.823 & 0.631 & 1.960 & “ & “ \\
\hline 3 & & 3.18 & 1.034 & 1.011 & 1.960 & “ & “ \\
\hline 4 & Supervise the subordinates at work and correct errors & 3.32 & 0.590 & 1.210 & 1.960 & “ & “ \\
\hline 5 & Keep records or purcnases as tney are made & 2.88 & 1.141 & 0.873 & 1.960 & “ & “ \\
\hline 6 & $\begin{array}{l}\text { Maintain a clean environment within the enterprise to } \\
\text { specifications }\end{array}$ & 3.19 & 0.983 & 0.432 & 1.960 & “ & “ \\
\hline 8 & $\begin{array}{l}\text { Utilize resources for maximization of business profit and } \\
\text { efficiency }\end{array}$ & 3.03 & 0.862 & 0.663 & 1.960 & “ & “ \\
\hline 9 & Motivate subordinates regularly through good remuneration. & 2.92 & 0.791 & 0.521 & 1.960 & “ & “ \\
\hline & $\begin{array}{l}\text { Provide good security for the human and material resources in } \\
\text { the enterprise }\end{array}$ & 3.12 & 0.630 & 0.484 & 1.960 & “ & “ \\
\hline 10 & Provide safety measures for the entire enterprise & 268 & 1012 & 0833 & 1960 & “ & " \\
\hline 11 & Relate cordially with customers within the enterprise & 3.30 & 0.841 & 0.572 & 1.960 & “ & “ \\
\hline 12 & $\begin{array}{l}\text { Check products for expiration and complain to appropriate } \\
\text { agencies }\end{array}$ & 3.21 & 1.180 & 0.511 & 1.960 & “ & “ \\
\hline 13 & Provide feedback to suppliers on their goods or services & 3.05 & 0.883 & 1.320 & 1.960 & “ & “ \\
\hline 14 & & 3.00 & 0.910 & 1.032 & $\begin{array}{l}1.900 \\
1.960\end{array}$ & “ & “ \\
\hline
\end{tabular}

Data on table 2 presents the mean ratings of respondents on entrepreneurial skills required by secondary school graduates in implementing business plans in the tourism industry. The table shows that the fourteen isolated items recorded mean ratings between 2.68 and 3.30 which are above 2.50 cut-off point on a four point scale. The result shows that the fourteenentrepreneurial skilled items are required by secondary school graduates in implementing business plans in the tourism industry in the tourism industry. This implies that secondary school graduates require skills in procuring materials and goods, organizing resources, distributing jobs among subordinates, keeping good purchase and sales records about the enterprises. Others includes maintaining a clean business environment, motivating subordinates, providing security and safety measures in the enterprise and maintaining a cordial relationship with customers in order to satisfactorily implement business plans within the tourism industry for profit maximization.

Similarly, data on test of the hypothesis revealed that the fourteen entrepreneurial skill items had their calculated t-values ranged from 0.421 to 1.320 which were less than table value of 1.960 at .05 level of significance and 354 degree of freedom. This indicated that there is no significant difference in the mean ratings of the two groups of respondents on the fourteen skill items required by secondary school graduates for 
implementing business plans in the tourism industry. The null hypothesis was upheld for the for the nine entrepreneurial skill items.

\section{Research Question 3}

What entrepreneurial skills are required by secondary school graduates in the marketing of products in the tourism industry?

\section{Hypothesis Three}

There is no significant difference in the mean ratings of tourism personnel and vocational subject teachers on entrepreneurial skills required by secondary school graduates in the marketing of products in the tourism industry

The data for answering research question three and hypothesis three are presented in table three.

Table 3Mean rating and t-test Analysis of the Responses of Vocational Subject teachers and Tourism personnel on Entrepreneurial Skills Required by Secondary School Graduates in the Marketing of Products in the tourism industry

\begin{tabular}{|c|c|c|c|c|c|c|c|}
\hline SN & Item Statement & $\overline{\mathrm{X}}$ & SD & t-cal & t-tab & RQ & Ho \\
\hline 1 & Make a notice board to market the enterprise & 3.33 & 0.86 & 0.644 & 1.960 & Rqrd & NS \\
\hline 2 & $\begin{array}{l}\text { Advertise the enterprise to customer through radio and } \\
\text { television }\end{array}$ & 3.18 & 1.00 & 0.734 & 1.960 & “ & “ \\
\hline 3 & $\begin{array}{l}\text { Fix prices for products according to grade or purchase } \\
\text { prices }\end{array}$ & 3.08 & 0.93 & 0.542 & 1.960 & “ & “ \\
\hline 4 & Decide on payment mode by customer & 3.22 & 0.82 & 0.611 & 1.960 & “ & “ \\
\hline 5 & Keep records of progress in the enterprise & 3.52 & 0.84 & 0.812 & 1.960 & “ & “ \\
\hline 6 & $\begin{array}{l}\text { Rewards customers with gift items to sustain their } \\
\text { patronage }\end{array}$ & 2.98 & 0.69 & 0.681 & 1.960 & “" & “ \\
\hline 7 & $\begin{array}{l}\text { Interact with customers to determine their preference } \\
\text { with regards to goods and services }\end{array}$ & 3.02 & 0.84 & 0.562 & 1.960 & “ & “ \\
\hline 8 & $\begin{array}{l}\text { Prepare a profit and loss account monthly and yearly } \\
\text { Consider expansion of the enterprise based on profits }\end{array}$ & 3.41 & 1.01 & 0.713 & 1.960 & “ & “ \\
\hline & & 2.87 & 0.62 & 0.680 & 1.960 & “ & “ \\
\hline
\end{tabular}

Table 3 presents the mean ratings of respondents on entrepreneurial skills required by secondary school graduates in the marketing of products in the tourism industry. The table shows that the nine isolated items recorded mean ratings between 2.87 and 3.52 which are above 2.50 cut-off point on a four point scale. The result shows that the nine skilled items are required by secondary school graduates in the marketing of products in the tourism industry. The result shows that for secondary school graduates to market products within the tourism industry they should possess skills in preparing notice boards to market the enterprise, advertising the enterprise through radio and television, fixing prices according to grades and purchase prices, deciding on payment modes, keeping records of business progress among others.

Data on test of the hypothesis revealed that the nine entrepreneurial skill items had their calculated tvalues ranged from 0.542 to 0.812 which were less than table value of 1.960 at .05 level of significance and 354 degree of freedom. This indicated that there is no significant difference in the mean ratings of the two groups of respondents on the nine skill items required by secondary school graduates for marketing of products in the tourism industry. The null hypothesis was upheld for the for the nine entrepreneurial skill items.

\section{Discussion of Results}

The data generated and analyzed from the research questions and hypotheses tested revealed that both vocational subject teachers and Tourism personnel agreed that the thirty two (32) entrepreneurial skills are required by secondary school graduates for success in the tourism industry. Findings on entrepreneurial skills requirements of secondary school graduates in planning for the establishment of small scale business out lets in the tourism industry showed that they need to be equipped with knowledge and skills on establishing goals and business standards, deciding on the nature of the business, developing rules and procedures for the enterprise, identifying supportive personnel and sources of funds among others to be able to effectively plan for the establishment of any business outlet in the tourism industry. This findings agree with Dimelu (2010) who conducted a study on resource management needs of secondary school graduates for success in interior decoration enterprise and identified competency items in planning as establishment of goals, deciding on nature (name, address and website) of business, development of rules and regulation for the business, identification of subordinates among others. The findings also reinforced the submission of Olaitan and Mama (2001) who stated 
that planning for any enterprise is the process of arranging and documenting activities before implementation and identified planning activities such as formulation of objectives, revision of the objectives periodically, budgeting, identification of sources of funds and labour among others to be essential to any enterprise. Long (2012) also stated thattourism development without proper planning and integration with local values and environment can lead to socio-cultural, environmental and economic damage.

The findings on entrepreneurial skills in implementing business plans in the tourism industry revealed that secondary school graduates need to be competent in procuring materials and goods, organizing resources, distributing jobs among subordinates, keeping good purchase and sales records about the enterprises. Others includes maintaining a clean business environment, motivating subordinates, providing security and safety measures in the enterprise and maintaining a cordial relationship with customers in order to successfully implement any business plans within the tourism industry. The findings agree with Dimelu (2010) who in the same study above identified thirteen human resource management competencies for secondary school students to be successful in interior decoration enterprise.Mbaiwa, (2003) explained that the quality of the environmental resources, both natural and man-made is very essential to the tourism industry and efforts should be consciously made to understand the complex relationships that exist between tourism and the environment through careful planning, organization and utilization of resources of the environment.

The findings on entrepreneurial skills in the marketing of products in the tourism industry indicated that secondary school graduates required skills in preparing notice boards to market the enterprise, advertising the enterprise through radio and television, fixing prices according to grades and purchase prices, deciding on payment modes, keeping records of business progress among others. The findings collaborates Dimelu's (2010) research evidence on competenciesin marketing required by secondary school graduates for success in interior decoration enterprise. The findings also agree with McCarthy and Perreault (1984) who described marketing as a process which involves buying and selling and identified activities such as identification of buyers, grading, transportation, storage, risk management, records keeping among others to be essential in every enterprise. Okoli (2001) noted that the development of an area for tourism results to economic benefits of foreign exchange earnings, government revenue, as well as provide employment opportunities.

The findings from the test of hypotheses revealed that there was no significant difference in the mean ratings of the responses of graduate tourism personnel and vocational subject teachers on the 32 entrepreneurial competencies required by secondary school graduates for success in the tourism industry. The implication of these findings is that the background and experience of the respondents did not exert any influence on their opinions on the skill items required by secondary school graduates for success in the tourism industry. The respondent did not vary in their opinions, that is, they were in support of the competencies required by secondary school graduates for success in the tourism industry.

\section{Conclusion and Recommendations}

The issue of unemployment and possession of entrepreneurial skills has occupied a central focus by Nigerian Government and Cross River State in particular. This has necessitated studies to determine the entrepreneurial skills requirements of youth for successful engagement in enterprises in the tourism sector which has become a fast growing enterprise in Nigeria. The acquisition of skills by individuals in the establishment and management of business outlets in the industry could help secondary school graduates who are mostly youths tobe gainfully employed so that they could be deviated from societal vices occasioned by idleness.

The study therefore identified entrepreneurial skills in the areas of planning to establish a business, implementing the plan and marketing of products required by secondary school graduates for success in any business outlet irrespective of the size in the tourism industry.

It was therefore recommended that:

1. The agricultural extension officers in the Ministry of Agriculture should use the identified entrepreneurship skills areas by the study to guide the secondary school graduates and members of young farmers club for successful entry into the tourism industry.

2. The Government of Cross River State through the assistance of curriculum planners should integrate the skills identified by this study into the state skill acquisition training programme for youths and adults in the tourism industry. 


\section{References}

[1] Ayeni, D. A. \&Ebohon, O. J. (2013).Exploring Sustainable Tourism in Nigeria for Developmental Growth. European Scientific Journal, 8(20): 126-140

[2] Dimelu, I. N. (2010). Resource Management Needs of Secondary School Graduates for Success in Interior Decoration Enterprise in Enugu State. Nigerian Vocational Association Jounal,15(1): 106-113

[3] Eja, E. (2010). The role of private sector participate in sustainable tourism development in Cross River State, Nigeria. International journal of business and social sciences. 2(2):153-160.

[4] Larry, E. (2005). The Cross River State tourism vision and policy. Mofinews 3:44-49.

[5] Long, P. H. (2012). Tourism Impacts and Support for Tourism Development in Ha Long Bay, Vietnam; An Examination of Residents Perceptions. Asian Social Sciences, 8(8):28-29.

[6] Mbaiwa, J. E. (2003). The Socio-Economic and Environmental Impacts of Tourism Development on the Okavango Delta, NorthWestern Botswana. Arid Environments, 54:447-467

[7] McCarthy, J. E. \&Perreault, W. D. (1984). Basic Marketing Approach. U. S. A.: Richard Irwin Inc.

[8] Nworgu, B.G. (2006). Educational Research, Basic Issues and Methodology. Nsukka: University Trust Publishers.

[9] Ochonogor, E.O \&Ohwovoriole, P. I. (2007). Equipping NCE Home Economics with skills for Entrepreneurship Development. Journal of Home Economics Research 9: 254-261.

[10] Ogungbade, F. E., Alkali, M \&Ibekwe, N.F. M. (2010). Work Skills Required by Secondary School Graduates for Entry into Groundnut Production Enterprise in Kaduna State. Nigerian Vocational Association Journal, 15(1): 114-122.

[11] Oh, C. O. (2005). The Contribution of Tourism Development to Economic Growth in the Korean Economy, Tourism Management, 26:39-44).

[12] Okoli, C. (2001). Tourism Development and Management in Nigeria.Enugu: Jee Publication

[13] Okorie, J. U. (2000). Developing Nigerians' Workforce. Enugu: Environs Publishers

[14] Olaitan, S.O \& Mama, R.O (2001) Principle and Practice of School farm Management. Owerri: Cape Publishers Intl Ltd.

[15] Onu, V. C. (2007). Repositioning Nigerian Youths for Economic Empowerment through Entrepreneurship Education. Journal of Home Economics Research 9: 254-261.

[16] Osinem, E.C. (2008).Managing Agricultural Education and Training: Resources, Principles and Methods. Enugu: Belony International Publishers.

[17] Osuala, E. C. (2004). Introduction to Research Methodology. Enugu: Cheston Agency Ltd.

[18] Uzoagulu, A. E. (1998). Practical Guide to Writing Research Project Report in Tertiary Institution. Enugu: John Jacobs Classic Publishers Ltd.

[19] World Tourism Organization (WTO) (2009). National and Regional Tourism Planning: Methodologies and case studies. London: Routlegde 